\title{
21-hydroxylase deficiency families with HLA identical affected and unaffected sibs
}

\author{
PAUL J SINNOTT*, PHILIP A DYER*, DAVID A PRICE + , RODNEYHARRIS * , \\ AND TOM STRACHAN* \\ From * the University Department of Medical Genetics, St Mary's Hospital, Manchester; and the Royal \\ Manchester Children's Hospital, Pendlebury, Manchester.
}

SUMMARY During our investigations of polymorphisms at, and in the immediate chromosomal $\stackrel{\sim}{\sim}$ vicinity of, the 21 -hydroxylase locus in families with 21 -hydroxylase deficiency, three families were found to show marked discordance in clinical features of HLA identical subjects. In one $\circ$ family, there is discordance between a boy with the simple virilising form of 21-hydroxylase 옹 deficiency and his two younger sisters, who are both HLA identical to their brother, but who $\vec{c}$ have additional salt wasting features. In the other two families, one subject is severely affected $\stackrel{\Xi}{5}$ and has very high 17-hydroxyprogesterone levels, but has an HLA identical sib who is asymptomatic and shows only slightly raised 17-hydroxyprogesterone levels. In all cases, HLA identity, as indicated by protein polymorphism studies (HLA-A, B, DR, C4A, C4B, and Bf $\vec{\oplus}_{0}$ typing), has been verified at the gene organisation level using 21-hydroxylase and complement $\mathrm{C} 4$. DNA probes. An HLA-Bw47 bearing haplotype in one of the latter families has not been transmitted to the affected child and appears to carry a normal $21-\mathrm{OHB}$ allele and two genes which specify C4A allotypes.

Approximately 90 to $95 \%$ of cases of congenital adrenal hyperplasia are attributable to a deficiency in steroid 21-hydroxylation. ${ }^{2}{ }^{2}$ The adrenal zona fasciculata is the site of 21-hydroxylation of 17 hydroxyprogesterone by a cytochrome P450c21. This represents one step in a glucocorticoid pathway which leads ultimately to the synthesis of cortisol. In addition, cytochrome $\mathrm{P} 450 \mathrm{c} 21$ mediates the 21hydroxylation of progesterone in a mineralocorticoid pathway culminating in the production of aldosterone. Although the glucocorticoid pathway appears to be largely confined to the zona fasciculata, the mineralocorticoid pathway occurs in the adrenal zona glomerulosa, and also in the adrenal zona fasciculata where its magnitude is small in comparison with cortisol synthesis. Deficiency in steroid 21-hydroxylase may lead to failure to convert 17-hydroxyprogesterone (17-OHP) to 11-deoxycortisol. The ensuing accumulation of precursor proximal to the 21-hydroxylase block is followed by shunting of 17-OHP into an androgen biosynthesis pathway, leading to overproduction of androgens and virilisation. Classical 21-hydroxylase deficiency

Received for publication 4 May 1988. Accepted for publication 8 June 1988. occurs in one in 5000 to 10000 births and results in $\frac{0}{3}$ ambiguous genitalia in the case of female births. Additionally, 50 to $80 \%$ of classical cases show an inability to conserve dietary sodium which, if untreated, may lead to death in the early neonatal period ('salt wasting'). In such cases, aldosterone $\frac{0}{3}$ synthesis is expected to be substantially impaired following a block in 21-hydroxylation of pro- $\frac{\delta}{\gamma}$ gesterone. Non-classical 21-hydroxylase deficiency

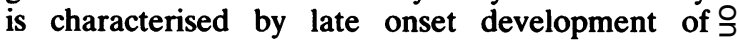
symptoms of androgen excess or by an apparent lack $\gg$ of symptoms ('cryptic form') and is found in $0.3 \%$ of Caucasians.

The inheritance of 21-hydroxylase deficiency is autosomal recessive and asymptomatic heterozy- $\mathcal{N}$ gous carriers may be identified by an abnormal $N$ steroid response to intravenous ACTH. Close genetic linkage of 21-hydroxylase deficiency to the $c$

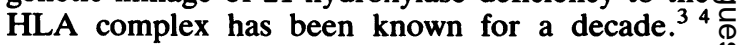
However, discordance in clinical symptoms between $\stackrel{?}{+}$ HLA identical sibs has been occasionally reported, notably with regard to discordance between the degree of salt wasting, ${ }^{56}$ and a proposal has been $\stackrel{\odot}{\Phi}$ advanced that the adrenal zona fasciculata and zona $\stackrel{\mathbb{Q}}{\varrho}$ glomerulosa are under separate genetic regulation. ${ }^{7}$ Recently, molecular mapping studies have 
assigned the 21-hydroxylase locus to the class III region of the HLA complex, flanked centromerically by class II HLA loci, and telomerically by class I HLA loci. Two 21-hydroxylase genes, 21-OHA and 21-OHB, have been uncovered, being located immediately centromeric to the complement C4A and $\mathrm{C} 4 \mathrm{~B}$ genes, respectively. ${ }^{8-10}$ Of these, only 21 OHB appears to be functional regarding 21hydroxylation of steroids, while the 21-OHA gene has been considered to represent a pseudogene. ${ }^{11-13}$ Analyses of the 21-OH/C4 gene region have shown a high incidence of apparent deletion of the 21-OHB gene associated with 21-hydroxylase deficiency. ${ }^{14-16}$ In particular, haplotypes with the very rare HLABw47 allele, which are strongly associated with salt wasting 21-hydroxylase deficiency, have been considered to be associated with concomitant 21OHB gene deletion, and a compound deletion of a 21-OHB gene and a C4B gene has been suggested from some studies. ${ }^{814} 16$ In the present investigation, we report some unusual 21-hydroxylase deficiency families which show profound discordance between the clinical features of sibs who appear to be HLA identical, both in terms of serologically defined polymorphism and in gene organisation at the $21-\mathrm{OH}$ and $\mathrm{C} 4$ loci. In one of these families, there is the additional unusual observation of HLA-Bw47 bearing haplotypes which appear to carry a functional 21-hydroxylase gene.

\section{Materials and methods}

17-HYDROXYPROGESTERONE ASSAYS

Serum 17-hydroxyprogesterone levels were assayed as described previously. ${ }^{17}$ Samples were taken at time zero and at 30 minutes and 60 minutes after an intravenous administration of $250 \mathrm{mg} \mathrm{ACTH} \mathrm{(syn-}$ acthen).

HLA ANTIGEN SEROLOGY

Typing for HLA-A and B antigens was carried out using the standard NIH technique, while HLA-DR typing was performed with peripheral blood B lymphocytes isolated by their adherence to nylon wool columns. All antisera were obtained locally or through mutual exhange with collaborating laboratories and were thoroughly screened using cell panels typed with International Histocompatibility Workshop antisera.

\section{FACTOR B TYPING}

Factor B (Bf) typing was conducted by standard techniques ${ }^{18}$ using high voltage electrophoresis of serum in agarose gels followed by immunofixation with specific goat antihuman factor B (Atlantic Antibodies).
COMPLEMENT C4 TYPING

After agarose gel electrophoresis of plasma or serum samples that had been treated with carboxypeptidase and desialated using neuraminidase, ${ }^{19}$ complement $\mathrm{C} 4$ types were identified by immunofixation with a specific antiserum to human $\mathrm{C4}$ (Atlantic Antibodies) and by a specific gel overlay containing sensitised sheep red blood cells and $\mathrm{C} 4$ deficient guinea pig serum.

\section{SOUTHERN BLOT HYBRIDISATION}

Genomic DNA samples were prepared from whole blood samples by standard methods. ${ }^{20}$ Individual restriction nuclease digestions were conducted overnight at $65^{\circ} \mathrm{C}$ using $8 \mu \mathrm{g}$ human genomic DNA and 25 units of enzyme essentially as recommended by the manufacturers (Boehringer-Mannheim). Digests were subjected to agarose gel electrophoresis $(0 \cdot 8 \%$ agarose in Tris-Borate-EDTA buffer, $3 \mathrm{~V} / \mathrm{cm}$, overnight) before transfer of resolved DNA fragments onto nylon membranes (Amersham HybondN) by standard techniques. ${ }^{21}$ Blots were prehybridised for five hours at $65^{\circ} \mathrm{C}$ in a solution of $5 \times$ SSC, $0.1 \%$ SDS, $0.25 \%$ Marvel (Cadbury), which contained $100 \mu \mathrm{g} / \mathrm{ml}$ denatured herring sperm DNA. Hybridisation was conducted overnight in a solution with the same composition as the prehybridisation solution, but supplemented by the addition of PEG-6000 to a final concentration of $6 \%$ and denatured radioactive DNA probe to a final concentration of $5 \mathrm{ng} / \mathrm{ml}$. The 21-hydroxylase gene probe used was a $1.8 \mathrm{~kb} K$ pnI-EcoRI fragment (21A-1.8). This was subcloned after appropriate digestion of a genomic clone, pSV4Kpn, that contained a $4 \mathrm{~kb} K p n I$ fragment derived from the cosmid clone, $\cos 1 \mathrm{E} 3 .^{9}$ The $21 \mathrm{~A}-1.8$ probe represented a portion of the 21-OHA gene which was equivalent to a region spanning from exon 4 to the beginning of the $3^{\prime}$ untranslated region of the functional 21-OHB gene. The C4 DNA probe was a 500 bp BamHI-KpnI fragment (C4B-500) subcloned from the cDNA clone pAT- $\mathrm{A}^{22}$ and represented a region at the extreme $5^{\prime}$ end of a full length cDNA copy of mRNA expressed by the $\mathrm{C} 4 \mathrm{~B}$ gene. Both probes were radiolabelled with $\left[\alpha{ }^{32} \mathrm{P}\right.$ dCTP] to a specific activity exceeding $10^{9} \mathrm{cpm} / \mu \mathrm{g}$ using a hexanucleotide priming procedure. ${ }^{23}$ Hybridisation washes were concluded in a solution of $0.1 \times \mathrm{SSC}$ at $65^{\circ} \mathrm{C}$ before conventional autoradiography at $-70^{\circ} \mathrm{C}$. Densitometry of autoradiographic signals was conducted on a LKB-Brumma 2202 Ultroscan Laser Densitometer.

\section{Results}

Our investigations of 21-hydroxylase deficiency 
families have identified three families $(\mathrm{A}, \mathrm{B}, \mathrm{C}$, fig 1) where there is discordance in clinical symptoms between sibs who are HLA identical on the basis of serologically defined polymorphisms (HLA-A, B, DR, C4A, C4B, Bf typing).

The three HLA identical affected children in family A all showed abnormally high 17hydroxyprogesterone (17-OHP) levels (table). The two sisters, II. 2 and II.3, showed marked virilisation and also salt loss in the early neonatal period. The oldest child, a boy (II.1), was pubertal at 10 years of age and when fully grown was short in stature compared to his parents. However, in other respects

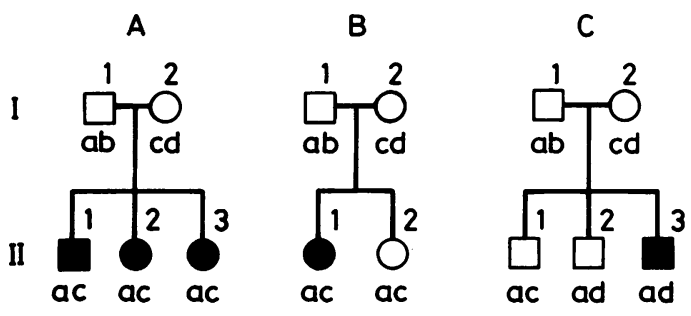

FIG 1 Pedigrees of families $A, B$, and $C$. Haplotypes are as follows. $A: a=D R 1 B 14 A 3 ; b=D R 4 B 44 A 2 ; c=D R 2 B 5$ $A 2 ; d=D R 4$ B44 A2. B: $a=D R 4 C 4 B Q o$ C $4 A 3$ BfS B44 $A 2 ; b=D R 1$ C4BQo C4A3 BfF B44 A2; $c=D R 4 C 4 B 1$ C4A3 BfS B40 A30; d=DR6 C4BQo C4A3 B44 A32. C: $a=D R 7$ C4BQo C4A1 BfF Bw47 A3; $b=D R 2 C 4 B 1$ C4A3 BfS B7 A1; $c=D R 4$ C4BQo C4A1 C4A3 BfF Bw47 $A 3 ; d=D R 6 C 4 B 5 C 4 A 4 B f S B 22 A 3$. he was clinically unremarkable and was not investi gated until after the birth of his sisters, whereupor? his tissue type was found to be identical to theirs.

In family B, the affected girl, II.1, had severe clitoromegaly and labial fusion while her HLA identical sister, II.2, showed no abnormal clinicaß features indicative of 21-hydroxylase deficiency» Plasma renin activity in the affected child was only minimally raised $(15 \mathrm{ng} / \mathrm{ml} /$ hour at six months of age). However, abnormally high 17-OHP levels in II. 1 were consistent with the simple virilising form of 21-hydroxylase deficiency, while her sister, II. 2 글 showed only slightly raised 17-OHP levels (table). iv Initial investigations in family $\mathrm{C}$ have beer? reported previously. ${ }^{17}$ The affected boy, II. $3 \overrightarrow{;}$ showed a failure to thrive in the early neonataP period with vomiting and weight loss. At three weeks, $\mathrm{Na}^{+}$was $113 \mathrm{mmol} / \mathrm{l}$ and $\mathrm{K}^{+}$was $8.0 \mathrm{mmol} / \mathrm{l}^{-}$ As shown in the table, he showed abnormally highw 17-OHP levels while his HLA identical brother II.2, showed no symptoms of 21-hydroxylase

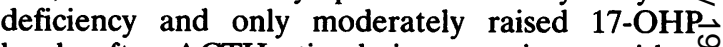
levels after ACTH stimulation, consistent with wo carrier status. Interestingly, the oldest child, II. 1 who is a HLA-Bw47 homozygote and shares ones HLA haplotype with his two brothers, appears to bes biochemically normal. The mother has a haplotypeo which carries the HLA-Bw47 antigen, but thiš haplotype is not the one that is transmitted to the affected child, and she, too, has normal 17-OHP levels (table).

In order to investigate the basis of the clinical

TABLE 17-hydroxyprogesterone levels of individual members of families $A, B$, and $C$ before and after $A C T H H_{0}$ stimulation. Basal 17-OHP levels were recorded after overnight dexamethasone suppression in the case of members of family $A$ only.

\begin{tabular}{|c|c|c|c|c|c|c|}
\hline \multirow[t]{2}{*}{ Family } & \multirow{2}{*}{$\begin{array}{l}\text { Form of } 21 \text { - } \\
\text { hydroxylase } \\
\text { deficiency }\end{array}$} & \multirow[t]{2}{*}{$\begin{array}{l}\text { Family } \\
\text { member }\end{array}$} & \multicolumn{3}{|c|}{$\begin{array}{l}\text { 17-OHP after } A C T H \\
\text { stimulation (nmolll) }\end{array}$} & \multirow[t]{2}{*}{ Status } \\
\hline & & & $\begin{array}{l}0 \\
\min \end{array}$ & $\begin{array}{l}30 \\
\min \end{array}$ & $\begin{array}{l}60 \\
\min \end{array}$ & \\
\hline $\mathbf{A}$ & SV/SW & \begin{tabular}{r|} 
I. 1 \\
I. \\
II. 1 \\
II .2 \\
II .3
\end{tabular} & $\begin{array}{l}6.6 \\
0.9 \\
3.6 \\
2.1 \\
5.8\end{array}$ & \begin{tabular}{l}
\multicolumn{1}{c}{$7 \cdot 9$} \\
ND \\
$453 \cdot 0$ \\
$370 \cdot 0$ \\
$360 \cdot 0$
\end{tabular} & $\begin{array}{r}10.1 \\
8.6 \\
578 \cdot 0 \\
401 \cdot 0 \\
467.0\end{array}$ & $\begin{array}{l}\text { Carrier?* } \\
\text { Carrier?* } \\
\text { Affected (S } \\
\text { Affected (S } \\
\text { Affected (S }\end{array}$ \\
\hline B & SV & \begin{tabular}{r|} 
I.1 \\
I. \\
II. \\
II .2
\end{tabular} & $\begin{array}{r}9.5 \\
4 \cdot 0 \\
46 \cdot 0 \\
0.5\end{array}$ & $\begin{array}{r}13 \cdot 0 \\
13 \cdot 0 \\
880 \cdot 0 \\
12 \cdot 0\end{array}$ & $\begin{array}{r}16 \cdot 0 \\
13 \cdot 0 \\
1240 \cdot 0 \\
14 \cdot 5\end{array}$ & $\begin{array}{l}\text { Carrier } \\
\text { Carrier } \\
\text { Affected } \\
\text { Carrier }\end{array}$ \\
\hline C & SW & \begin{tabular}{r|} 
I. 1 \\
I. 2 \\
II. 1 \\
II. 2 \\
II. 3
\end{tabular} & $\begin{array}{r}8.0 \\
0.4 \\
3.6 \\
7.5 \\
1350.0\end{array}$ & $\begin{array}{r}11 \cdot 0 \\
6.0 \\
6 \cdot 0 \\
42 \cdot 0 \\
\text { ND }\end{array}$ & $\begin{array}{r}13 \cdot 0 \\
9 \cdot 0 \\
6 \cdot 0 \\
52 \cdot 0 \\
\text { ND }\end{array}$ & $\begin{array}{l}\text { Carrier } \\
\text { Carrier?† } \\
\text { Carrier?† } \\
\text { Carrier } \\
\text { Affected }\end{array}$ \\
\hline \multicolumn{7}{|c|}{$\begin{array}{l}\text { *17-OHP levels within the normal range but expected to be obligate carriers. } \\
+17-\text { OHP levels within the normal range; carrier status uncertain. }\end{array}$} \\
\hline
\end{tabular}


discordance between such apparently HLA identical subjects, and of HLA-Bw47 bearing haplotypes that do not appear to be associated with 21-hydroxylase deficiency, we have used a 21-hydroxylase gene probe, $21 \mathrm{~A}-1 \cdot 8$, and a complement $\mathrm{C} 4 \mathrm{cDNA}$ probe, C4B550, to identify DNA polymorphism in the 21-OH/C4 gene region in all members of families $\mathrm{A}, \mathrm{B}$, and $\mathrm{C}$. By using these probes against genomic Southern blots of DNA samples from family members, it is possible to identify gene deletions and gene replacement events at the $21-\mathrm{OH} / \mathrm{C} 4$ loci. Such events are known to be frequent in this region of chromosome 6 , and in companion studies of an additional 21 21-hydroxylase deficiency families, we have found that in $48 \%(20 / 42)$ of disease haplotypes the 21-hydroxylase deficiency is attributable to 21-OHB gene deletion, or to replacement of $21-\mathrm{OHB}$ by a gene resembling 21-OHA through gene conversion-like mechanisms (Sinnott et al, unpublished data). The remaining $52 \%$ of disease haplotypes showed the normal gene organisation, that is, 21B C4B 21A C4A, and in these cases the 21-hydroxylase deficiency is presumed to result from pathological point mutation or small insertion/deletion events in the 21-OHB gene that cannot be resolved by conventional DNA probing methods.

When Southern. filters of TaqI digested genomic DNA are hybridised with $21-\mathrm{OH}$ gene probes, such as $21 \mathrm{~A}-1 \cdot 8$, the $21-\mathrm{OHA}$ and $21-\mathrm{OHB}$ genes are characterised by $3.2 \mathrm{~kb}$ and $3.7 \mathrm{~kb}$ bands respectively. ${ }^{8}$ Hybridisation of $\mathrm{C}^{-5^{\prime}}$ probes, such as C4B550, to the same filters can distinguish C4A genes (characterised by a $7 \cdot 0 \mathrm{~kb}$ band) from $\mathrm{C} 4 \mathrm{~B}$ genes (characterised by either a $6.4 \mathrm{~kb}$ band, a 6.0 $\mathrm{kb}$ band, or a $5.4 \mathrm{~kb}$ band). ${ }^{14}$

Fig 2 shows autoradiograms of Southern hybridisation of the two probes against TaqI digested genomic DNA from all members of families A, B, and $C$. Densitometry analysis of the Southern hybridisation profiles shows identical patterns between HLA identical sibs in each of the three families. In family A each of the children, II.1, II.2, and II.3, shows equivalence in intensity for the three $\mathrm{C} 4$ specific bands of size $7.0 \mathrm{~kb}, 6.0 \mathrm{~kb}$, and $5.4 \mathrm{~kb}$. In addition, the children show a $2: 1$ ratio between the $21 \mathrm{~A}$ associated $3.2 \mathrm{~kb}$ band and the 21B associated $3.7 \mathrm{~kb}$ band. The maternal DNA sample (I.2) shows a ratio of 3:2 between the $C 4 B$ associated $6.0 \mathrm{~kb}$ and the $\mathrm{C} 4 \mathrm{~A}$ associated $7.0 \mathrm{~kb}$ bands and also a ratio of $3: 2$ between the 3.2 and $3.7 \mathrm{~kb}$ bands. The paternal DNA sample (I.1) shows a ratio of 2:1:2 for the 7.0 kb:6.0 kb:5.4 kb comparisons and a 3:2 ratio for the $3 \cdot 2 \mathrm{~kb}: 3 \cdot 7 \mathrm{~kb}$ comparison (data not shown). These data are consistent with the interpretation that both disease haplotypes have the organisation 21B C4B 21A C4B 21A C4A. One of these haplotypes (a) is an example of an HLA-B14 containing haplotype which has frequently been shown by others ${ }^{14-26}$ to exhibit this pattern of

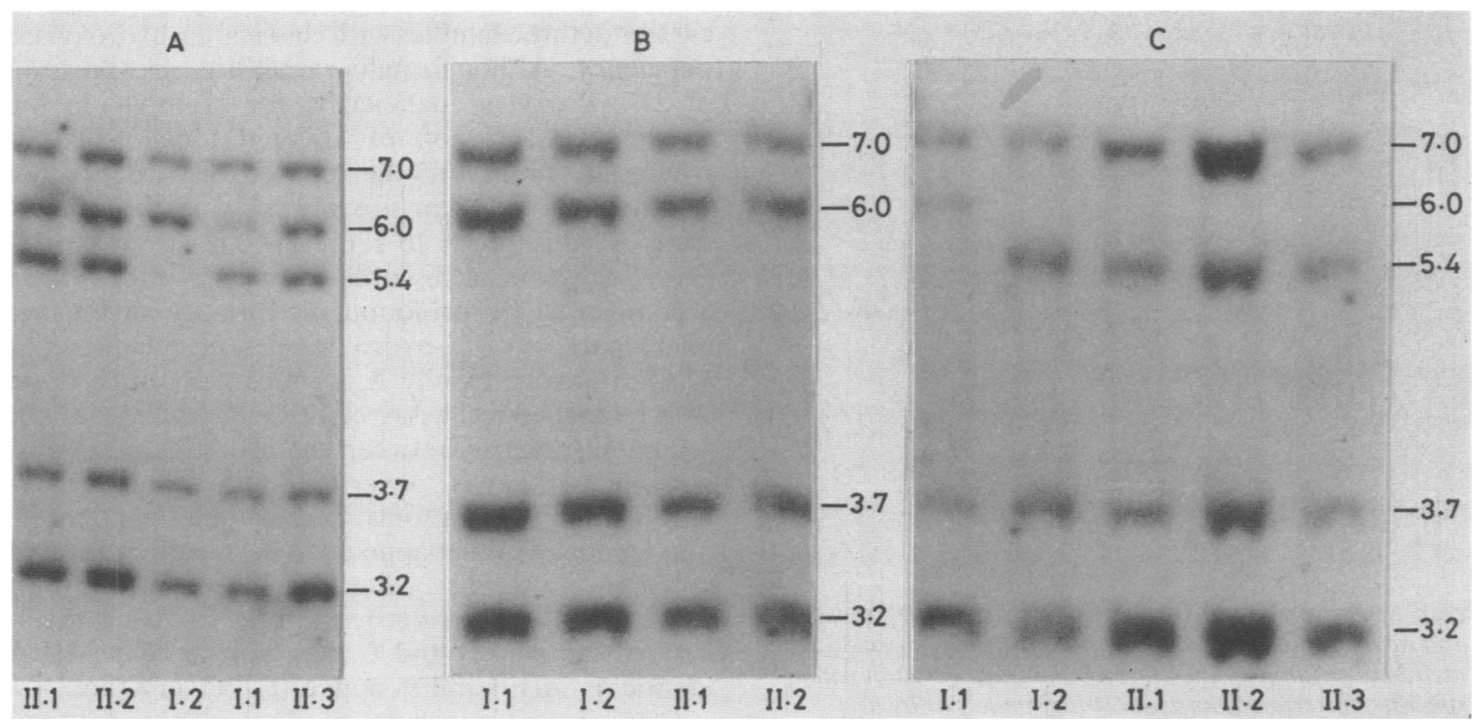

Fig 2 Southern autoradiogram of TaqI digested genomic DNA from indicated members of families $A, B$, and $C$, probed simultaneously with the 21-hydroxylase specific probe, $21 A-1 \cdot 8$, and the complement C4 specific probe, C4B550. Numbers denote the size of bands in kilobases. 
gene organisation at the $21-\mathrm{OH}$ and $\mathrm{C} 4$ loci. In disease haplotypes of this type, 21-hydroxylase deficiency is expected to be attributable to a pathological point mutation or a small insertion or deletion in the single 21-OHB gene.

In family $B$ equivalent analyses show that each family member shows a $1: 1$ ratio for the $7.0 \mathrm{~kb}$ and $6.0 \mathrm{~kb} \mathrm{C} 4$ bands, and also for the 3.2 and $3.7 \mathrm{~kb} 21$ $\mathrm{OH}$ bands. These results are consistent with a normal organisation of $21-\mathrm{OH}$ and $\mathrm{C} 4$ genes, that is, 21B C4B 21A C4A, on each haplotype, and the disease haplotypes are again expected to carry undetected pathological point mutation in the 21 OHB gene.

In family $\mathrm{C}$ densitometry analysis of the Southern hybridisation profile of DNA representing the father (I.1) and his three sons (II.1, II.2, and II.3) shows in each case a 2:1 ratio in intensity between the C4A associated 7.0 kb TaqI band and the C4B associated $6.0 \mathrm{~kb}$ (II.1) or $5.4 \mathrm{~kb}$ (II.1, II.2, II.3) bands, and also a $2: 1$ ratio between the $3.2 \mathrm{~kb}$ and $3.7 \mathrm{~kb}$ bands. This is consistent with the interpretation that haplotypes $\mathrm{b}$ and $\mathrm{d}$ carry the conventional organisation of $21-\mathrm{OH}$ and $\mathrm{C} 4$ genes, with the 21-OHB gene on disease haplotype $d$ apparently carrying a pathological point mutation. However,

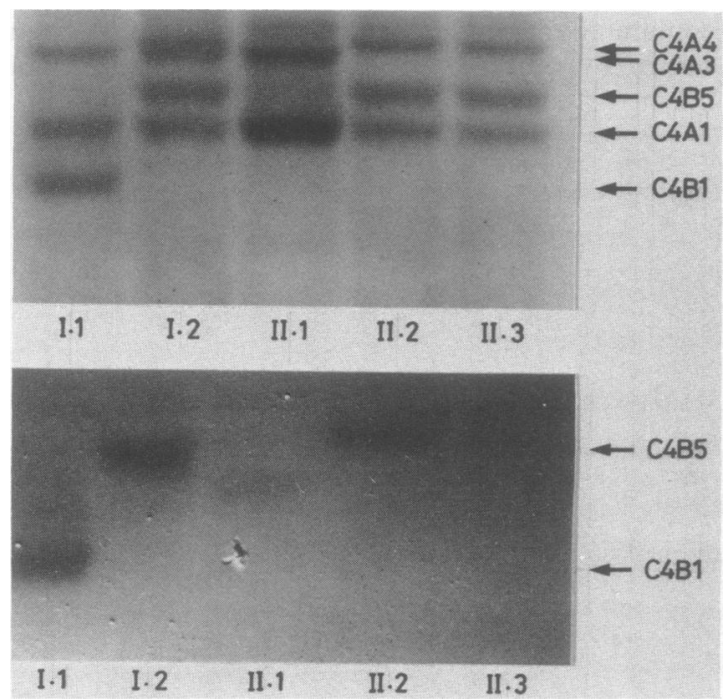

FIG 3 Agarose gel electrophoresis of carboxypeptidase B and neuraminidase treated serum samples of indicated members of family $C$, followed by immunofixation with $a$ specific antiserum to human C4 (left panel) or by a haemolytic gel overlay (right panel). Markers to the right of panels correspond to the electrophoretic positions of indicated C4 alleles as determined using parallel controls (not shown). the a haplotype, DR7 Bw47 A3, appears to show compound deletion of the $21 \mathrm{~B}$ and $\mathrm{C} 4 \mathrm{~B}$ genes, $\mathrm{a} \&$ has been suggested by the findings of several other groups. $^{814}$ In addition, the maternal DN sample (I.2) reproducibly shows equivalence in intensity between the two C4 TaqI bands $(7.0 \mathrm{kB}$ and $5.4 \mathrm{~kb}$ ) and also between the two 21-OH band $(3.7 \mathrm{~kb}$ and $3.2 \mathrm{~kb})$, consistent with a conventionat 21-OH/C4 gene organisation for both haplotype \& and also the Bw47 bearing haplotype c. However complement allotyping identifies three $\mathrm{C} 4 \mathrm{~A}$ antie gens in the mother (C4A1, C4A3, and C4A4) an $\bar{\Phi}$ two C4A antigens in the father (C4A1, C4A3) (fig 3). As II. 2 and II. 3 both show only C4A1 and C4A in equal intensity, we infer that the C4A4 allele only is carried on haplotype d, while the C4A1 and C4AP alleles are carried on haplotype $c$. The presence in II. 1 of a C4A1 band at twice the intensity of a companion $\mathrm{C} 4 \mathrm{~A} 3$ band is explicable by inheritance of haplotype $c$ which bears the $\mathrm{C} 4 \mathrm{~A} 1$ and $\mathrm{C} 4 \mathrm{~A}$ 辛 alleles, and of haplotype a which carries the C4A allele. Consequently, haplotype $c$ appears to have a 21B C4A/C4B 21A C4A gene organisation, whereo $\mathrm{C} 4 \mathrm{~A} / \mathrm{C} 4 \mathrm{~B}$ signifies a fusion gene that resembles $\mathrm{C} 4 \mathrm{~A}$ at the complement allotyping level (either C4A1 of C4A3), but resembles $C 4 B$ at the DNA level bs showing a $5.4 \mathrm{~kb}$ TaqI RFLP.

\section{Discussion}

We have investigated the profound discordance i clinical symptoms between apparently HLA identi cal sibs in three families with classical 21-hydroxylase. deficiency. Although mild variability of expressio of 21-hydroxylase deficiency, for example, in the extent of virilisation of affected female sibs, is commonly observed, the marked discordance be tween HLA identical sibs observed in the presen $\$$ study would appear to represent an extreme posi tion. Such clinical discordance may or may not be accompanied by profound discordance in bioche $\rightarrow$ mical markers of 21-hydroxylase deficiency, such as. 17-OHP levels. Family $A$ is an example of the typa where biochemical assay of 17-OHP levels does no? readily distinguish between the HLA identical sibs but where there is, nevertheless, marked discord ance in clinical symptoms. Such families may not be uncommon. ${ }^{5}$ What appears to be more remarkable is the profound discordance in both clinical symp toms and 17-hydroxyprogesterone levels in mem? bers of families B and C who appear to be HLAD identical. Such families appear to be very rare.

Clinical and biochemical discordance betweer apparently HLA identical subjects can be attribute $\overrightarrow{\mathbb{P}}$ either to genetic differences within the HLA como plex of these persons, or to differential involvement 
of factors other than those mapping to the HLA complex. As there is no easy way of measuring steroid 21-hydroxylase activity directly in the different subjects, we have to rely on demonstration of abnormal levels of metabolites proximal and distal to the presumed enzymic block, and on the clinical symptoms consequent upon these. Accordingly, differences in the regulation of the relevant metabolic pathways at the hypothalamic/pituitary levels may have a profound influence on metabolite levels and the clinical expression of 21-hydroxylase deficiency. In this regard it has often been observed that persons with 21-hydroxylase deficiency maintain naturally raised 17-hydroxyprogesterone levels throughout life, whereas natural imbalance in $\mathrm{Na}^{+} / \mathrm{K}^{+}$levels, causing early neonatal salt wasting symptoms, may not be evident in the same subject later in life. Feedback inhibition by cortisol of ACTH production could conceivably vary considerably owing to differences between HLA identical sibs in the set point or threshold cortisol levels that determine ACTH inhibition. In the present investigation, the affected child in family B (II.1) showed a normal basal serum cortisol level of $350 \mathrm{nmol} / \mathrm{l}$, which increased to 1800 then $2000 \mathrm{nmol} / 1$ after 30 and 60 minutes respectively of stimulation by ACTH in the synacthen test. The corresponding figures for her unaffected, HLA identical sister, 195, 670, and $845 \mathrm{nmol} / 1$ respectively, were lower but also in the normal range, which, together with the 17-OHP results, is consistent with differential metabolic drive in the glucocorticoid pathways of the sibs.

Clinical discordance in the absence of significant differences in 17-OHP levels of HLA identical subjects is most easily explained by differential regulation of 21-OH expression by factors that do not map to the HLA complex. However, it is conceivable that profound clinical discordance, accompanied by marked discordance between the 17-OHP levels, of apparently HLA identical subjects could alternatively be the result of genetic differences mapping within the HLA complex of such subjects. For example, one of the parents may not be a carrier of 21-OH deficiency and differential germinal mutation at the $21-\mathrm{OH}$ locus in this subject could account for the required genetic differences between his or her apparently HLA identical children. Our companion studies on other British classical 21-hydroxylase deficiency families have indicated that approaching $50 \%$ of pathological mutations at the $21-\mathrm{OH}$ locus involve gene deletion or replacement of the 21-OHB gene by a gene resembling 21-OHA. Consequently, our first step in analysing possible genetic differences at the $21-\mathrm{OH}$ locus in apparently HLA identical sibs was to examine the evidence for differential gene deletion/ duplication/replacement events at the $21-\mathrm{OH} / \mathrm{C} 4$ loci in those concerned. Out of the six disease haplotypes in families $\mathrm{A}, \mathrm{B}$, and $\mathrm{C}$, three carried an abnormal gene organisation indicative of such mutational events, but no differences could be detected in the 21-OH/C4 gene organisation of HLA identical sibs. In the case of family C, the same paternal HLA haplotype, DR7 Bw47 A3, is inherited by all three children and in each case Southern hybridisation against TaqI digested genomic DNA appears to suggest a deletion of the $21-\mathrm{OHB}$ and $\mathrm{C} 4 \mathrm{~B}$ genes. However, in the other five disease haplotypes, there remains the possibility of undetected differential point mutation at the $21-\mathrm{OH}$ locus in equivalent haplotypes in HLA identical sibs. We are currently addressing this possibility by DNA cloning and sequencing studies.

Other possible explanations for the discordance between apparently HLA identical sibs that involve genetic differences mapping to the HLA complex include differential paternity, double cross over, large scale gene rearrangements, and gene conversion. Of these, we have eliminated the possibility of differential paternity (possibly involving close male relatives) of HLA identical sibs: all Southern hybridisation bands detected in the HLA identical sibs by a hypervariable minisatellite DNA probe ${ }^{27}$ can be derived from the presumed parents (data not shown). Also, double cross over is an extremely unlikely proposition because of the molecular distances involved (about $1050 \mathrm{~kb}$ from HLA-DR to HLA-B). The rare possibility of large scale gene rearrangements that result in translocation of the 21-OH gene outside the HLA complex can be investigated by long range mapping using pulsed field Southern blotting, while DNA cloning and sequencing studies may be expected to show clustered nucleotide differences characterising differential mutation owing to gene conversion-like mechanisms.

Irrespective of the mechanism underlying clinical and biochemical discordance between apparently HLA identical sibs, the evidence for discordance introduces an extra, small degree of uncertainty in prenatal diagnosis of 21-hydroxylase deficiency. ${ }^{28}$ Any diagnosis, whether on the basis of serologically defined or DNA based polymorphisms, that relies on the demonstration of HLA identity between a previously affected child and a fetus in a subsequent pregnancy will occasionally admit false positives. It is equally possible that, on occasions, apparent success in prenatal treatment of 21-hydroxylase deficiency may derive from such naturally occurring discordance between HLA identical sibs.

Finally, the HLA-Bw47 containing maternal haplotype in family $\mathrm{C}$ which is not transmitted to the 
affected child (DR4 Bw47 A3) appears to have an exceptional gene organisation at the $21-\mathrm{OH} / \mathrm{C} 4$ loci. This haplotype appears to contain two $\mathrm{C} 4$ genes, one of which is a conventional C4A gene. The other C4 gene resembles a C4B gene at the DNA level, but specifies a $\mathrm{C} 4 \mathrm{~A}$ allotype and may have arisen by a gene conversion-like mechanism, as recently proposed in the case of a C4A6 C4A11 C4BQo haplotype ${ }^{29}$ Additionally, Southern hybridisation using a 21-OH gene probe against genomic DNA from the mother in family $\mathrm{C}$ shows no evidence for reduced representation of the $3.7 \mathrm{~kb}$ TaqI band associated with the 21-OHB gene, which in other reports has been suggested to reflect $21-\mathrm{OHB}$ gene deletion or replacement of 21-OHB by 21-OHA. We have obtained a similar finding for one DR7 Bw47 A3 haplotype (Sinnott et al, unpublished data), and a similar lack of 21-OHB deletion in DR7 Bw47 A3 haplotypes has recently been reported in the Old Order Amish. ${ }^{30}$ This finding endorses the view that Bw47 bearing haplotypes are heterogeneous with regard to their accompanying 21-OHB alleles, and consequently are not always associated with 21-OHB gene deletion as previously supposed. In the majority of cases, there is a null 21-OHB allele owing to 21-OHB gene deletion or to 21-OHB gene replacement events, ${ }^{31}$ which is strongly associated with salt wasting congenital adrenal hyperplasia. However, occasionally, Bw47 bearing haplotypes carry normal $21-\mathrm{OHB}$ alleles.

We are grateful to Irene Smeaton for technical assistance, to Michael Carroll for a gift of the pAT$A$ and pSV4Kpn clones, to Alec Jeffreys for a gift of the hypervariable minisatellite probe $6 \cdot 3$, to David Anderson and Simon Collier for helpful discussions and comments on the manuscript, and to our phlebotomist, Gill Reed.

\section{References}

1 White PC, New MI, Dupont B. Congenital adrenal hyperplasia. Parts 1 and 2. N Engl J Med, 1987;316:1519-24, 1580-6.

2 Miller WL, Levine LS. Molecular and clinical advances in congenital adrenal hyperplasia. J Pediatr 1987;111:1-17.

${ }^{3}$ Dupont B, Oberfield SE, Smithwick EM, Lee TD, Levine LS. Close genetic linkage between HLA and congenital adrenal hyperplasia (21-hydroxylase deficiency). Lancet 1977;ii:130912.

4 Price DA, Klouda PT, Harris R. HLA and congenital adrenal hyperplasia linkage confirmed. Lancet 1978;i:930-1.

5 Rosenbloom AL, Smith DW. Varying expression for salt-losing in related patients with congenital adrenal hyperplasia. Pediatrics 1966;38:215-9.

6 Stoner E, Dimartino-Nardi J, Kuhnle U, Levine LS, Oberfield SE, New MI. Is salt-wasting in congenital adrenal hyperplasia due to the same gene defect as the fasciculata defect? Clin Endocrinol 1986;24:9-20.

7 Kuhnle U, Chow D, Rapaport R, Pang S, Levine LS, New MI. The 21-hydroxylase activity in the glomerulosa and fasciculata of the adrenal cortex in congenital adrenal hyperplasia. J Clin Endocrinol Metab 1981;52:534-44.

8 White PC, Grossberger D, Onufer BJ, et al. Two genes encoding steroid 21-hydroxylase are located near the genes encoding the fourth component of complement in man. Proc Natl Acad Sci USA 1985;82:1089-93.

9 Carroll MC, Campbell RD, Porter RR. Mapping of steroid 21 hydroxylase genes adjacent to complement component $\mathrm{C} 4$ genes in HLA, the major histocompatibility complex in man. Proces Natl Acad Sci USA 1985;82:521-5.

10 Dunham I, Sargent CA, Trowsdale J, Campbell RD. Molecular map of the human major histocompatibility complex by pulsed field gel electrophoresis. Proc Natl Acad Sci USA 1987;84 W 7237-41.

11 White PC, New MI, Dupont B. Structure of human steroid $21 \overline{\bar{B}}$ hydroxylase genes. Proc Natl Acad Sci USA 1986;83:5111-5.

12 Higashi Y, Yoshioka H, Yamane M, Gotoh O, Fujii-KuriyamaO Y. Complete nucleotide sequence of 2 steroid 21-hydroxylase- genes tandemly arranged in human chromosome: a pseudogeneand a genuine gene. Proc Natl Acad Sci USA 1986;83: 2841-5.

13 Rodrigues NR, Dunham I, Yu CY, Carroll MC, Porter RR Campbell RD. Molecular characterization of the HLA-linked steroid 21-hydroxylase B gene from an individual with congen ital adrenal hyperplasia. EMBO J 1986;6:1653-61.

14 Schneider PM, Carroll MS, Alper CA, et al. Polymorphism of the human complement $\mathrm{C} 4$ and steroid 21-hydroxylase genes. $J$ Clin Invest 1986;78:650-7.

15 Rumsby G, Carroll MC, Porter RR, Grant DB, Hjelm M Deletion of the steroid 21-hydroxylase and complement $\mathrm{C} 4$ genes in congenital adrenal hyperplasia. J Med Genet 1986;23 $204-9$.

16 Jospe N, Donohue PA, Van Dop C, Mclean RH, Bias WB Migeon CJ. Prevalence of polymorphic 21-hydroxylase geneू (CA21HB) mutations in salt-losing congenital adrenal hypero plasia. Biochem Biophys Res Commun 1987;142:798-804.

17 Klouda PT, Harris R, Price R. Linkage and association between HLA and 21-hydroxylase deficiency. J Med Genet 1980;17윽 337-41.

18 Alper CA, Boehnisch T, Watson L. Genetic polymorphism of the third component of human complement. J Exp Meạ. 1972;35:68-80.

${ }^{19}$ Sim E, Cross SJ. Phenotyping of human complement compo nent C4, a class-III HLA antigen. Biochem $J$ 1986;239:763-7.

20 Kunkel LM, Smith KD, Boyer SH, et al. Analysis of human Y음 chromosome-specific reiterated DNA in chromosome variants Proc Natl Acad Sci USA 1977;74:1245-9.

21 Southern EM. Detection of specific sequences among DNA fragments separated by gel electrophoresis. J Mol Biol 1975;98? 503-17.

22 Belt KT, Carroll MC, Porter RR. The structural basis of the multiple forms of human complement component $\mathrm{C} 4$. Cets 1984;36:907-14.

${ }^{23}$ Feinberg AP, Vogelstein B. A technique for radiolabelling DNA restriction endonuclease fragments to high specific activity-addendum. Anal Biochem 1984;137:266-7.

24 Boehm BO, Rosak C, Boehm TLJ, Kuehnl P, White PCNิ Schoffling K. Classical and late-onset forms of congenita adrenal hyperplasia caused by $21-\mathrm{OH}$ deficiency reveal differen? alterations in the $\mathrm{C} 4 / 21-\mathrm{OH}$ gene region. Mol Biol Med 1986;3:437-48.

25 Garlepp MJ, Wilton AN, Dawkins RL, White PC. Rearrange ment of 21-hydroxylase genes in disease-associated MHC supratypes. Immunogenetics 1986;23:100-5.

26 Mornet E, Couillin P, Kutten F, et al. Associations betweep? restriction fragment length polymorphisms detected with $\mathbb{R}$ probe for human 21-hydroxylase (21-OH) and two clinical form\$
of 21-OH deficiency. Hum Genet 1986;74:402-8.

27 Jeffreys AJ, Wilson V, Thein SL. Hypervariable 'minisatellite regions in human DNA. Nature 1985:314:67-73. 
${ }^{28}$ Strachan T, Sinnott PJ, Smeaton I, Dyer PA, Harris R. Prenatal diagnosis of congenital adrenal hyperplasia. Lancet 1987;ii: 1272-3.

${ }^{29}$ Giles CM, Uring-Lambert B, Boksch W, et al. The study of a French family with two duplicated C4A haplotypes. Hum Genet 1987;77:359-65.

30 Donohue PA, Van Dop C, Migeon CJ, McLean RH, Bias WB. Coupling of HLA-A3, Cw6, Bw47, DR7 and a normal CA21HB steroid 21-hydroxylase gene in the old order Amish. J Clin Endocrinol Metab 1987;65:980-6.
${ }^{31}$ Matteson KJ, Phillips JA III, Miller WL, et al. P450XXI (steroid 21-hydroxylase) gene deletions are not found in family studies of congenital adrenal hyperplasia. Proc Natl Acad Sci USA 1987;84:5858-62.

Correspondence and requests for reprints to Dr T Strachan, Department of Medical Genetics, St Mary's Hospital, Hathersage Road, Manchester M13 0JH. 